\title{
DOI https://doi.org/10.30525/978-9934-26-044-5-26
}

\section{МОТИВИ ТА ІНТЕРЕСИ СТУДЕНТІВ ДО ЗАНЯТЬ ФІЗИЧНИМ ВИХОВАННЯМ У ЗАКЛАДІ ВИЩОЇ ОСВІТИ}

\author{
Чуйко О. О. \\ кандидат наук з фізичного виховання і спорту, \\ викладач кафедри боксу, боротьби та важкої атлетики \\ Придніпровська державна академія фізичної культури і спорту \\ м. Дніпро, Украӥна \\ Чернявська О. А. \\ викладач кафедри фізичного виховання \\ Національна металургійна академія Украӥни \\ м. Дніпро, Украӥна
}

Вступ. Мотивація - це співвіднесення цілей, що стоять перед людиною, яких вона прагне досягти, i внутрішньої активності особистості, тобто ії бажань, потреб і можливостей. Потреби спонукають людину до активності, а мотив - до спрямованої діяльності $[5,6]$.

Поява потреб зумовлює ряд вчинків людини, що супроводжується внутрішньою психічною і зовнішньою активністю та бажанням зняти внутрішню напругу. Людина прагне знайти вихід із становища, яке іiї не задовольняє, вона ставить перед собою мету і спрямовує свої зусилля для іiі досягнення. Щоб з'ясувати зміст активності, необхідно визначити іiї спонукальні причини.

Формування мотивів відбувається під впливом внутрішніх факторів (наприклад потреб) або зовнішніх - заохочення, покарання тощо. Незалежно від того, яке визначення дати мотивації, іiі вивчення повинно обгрунтувати поведінку особи, виявити внутрішні і зовнішні фактори, які впливають на переконання чинити саме так, а не інакше $[1,2]$.

Будь-яка діяльність людини, будь-які акти поведінки у процесі реалізації конкретизуються як результат відображення умов зовнішнього середовища, що постійно змінюється, і як результат змін психічних можливостей, внутрішніх потреб особистості як суб'єкта діяльності. Мотивація стає тим складним механізмом взаємовідношень особистості, зовнішніх і внутрішніх факторів поведінки, які зумовлюють появу, спрямування, а також способи втілення конкретних форм діяльності $[3,4]$.

Саме тому урахування мотивів молоді при заняттях фізичними вправами дозволить підвищити ефективність процесу фізичного виховання у закладі вищої освіти. 
Мета - визначити основні мотиви студентів закладу вищої освіти до занять фізичним вихованням.

Результати. 3 метою визначення спортивних уподобань та мотивації студентів до фізичної активності нами проведено анкетування юнаків. В анкетуванні взяли участь 77 студентів, які навчаються на I - II курсах Придніпровської державної академії будівництва та архітектури (ПДАБА) за спеціальностями «Промислове та цивільне будівництво», «Економіка підприємства».

Серед опитаних студентів $68,8 \%$ постійно відвідують заняття 3 фізичного виховання у ЗВО, $31,2 \%$ - здійснюють це нерегулярно. Заняття з фізичного виховання для студентів I - II курсів закладу вищої освіти проводяться двічі на тиждень по 2 академічних години кожне.

Основними мотивами відвідування занять 3 дисципліни «Фізичне виховання» $€$ : покращення функціонального стану організму $(54,5 \%)$, оволодіння новими руховими вміннями та навичками $(42,8 \%)$, розвиток фізичних якостей $(38,9 \%)$, покращення здоров'я $(36,4 \%)$, отримання заліку $(25,9 \%)$.

На питання «Чи задовольняе Вас зміст занять 3 фізичного виховання?» юнаки відповіли, що задовольняє - 23,4\%, не задовольняє $-13 \%$, частково $-63,6 \%$.

На заняттях 3 фізичного виховання юнаки хотіли б займатися сучасними видами рухової активності $(54,5 \%)$, мати індивідуальний підхід до планування та розподілу фізичних навантажень $(42,8 \%)$, більш різноманітні вправи, що виконуються на заняттях $(32,5 \%)$, отримувати більше теоретичних відомостей про різні види спорту, вплив фізичних вправ на організм і т.ін. $(24,7 \%)$, змінити організацію занять (13\%).

Результати опитування свідчать, що лише $35,1 \%$ юнаків займаються у спортивних секціях; $19,5 \%$ - займаються самостійно; $28,5 \%$ обмежуються тільки обов'язковими заняттями з фізичного виховання в 3ВО, a $16,9 \%$ - практично не займаються фізичними вправами. Найпопулярнішими видами спорту серед тих, хто займається, є футбол $(20,8 \%)$, загальна фізична підготовка $(19,5 \%)$, бокс $(7,8 \%)$, атлетична гімнастика $(6,5 \%)$.

Суб`єктивна оцінка фізичного стану студентів показала, що більшість 3 них вважають свій фізичний стан задовільним і поганим (по $35,1 \%$ ), добрим вважають $23,3 \%$, а відмінним $-6,5 \%$.

Серед респондентів 88,3\% виявили бажання займатися фізичними вправами у позанавчальний час. Серед напрямків фізичної активності у студентів викликають інтерес: єдиноборства (52\%), силові види спорту $(44,1 \%)$, ігрові види $(32,5 \%)$, легка атлетика, туризм, спортивне орієнтування $(24,7 \%)$, заняття у воді $(9,1 \%)$, різновиди гімнастики $(6,5 \%)$. 
Найбільша кількість студентів виявили цікавість до занять єдиноборствами (52\%). Нами також було запропоновано обрати конкретний напрямок єдиноборств для занять у позанавчальний час. Більшість опитаних обрали тайський бокс (50\%), східні види обрали $22,5 \%$; по $10 \%$ студентів обрали бокс і кікбоксинг; 7,5\% вибрали різновиди боротьби.

Основною метою занять фізичними вправами у юнаків є: корекція фізичного стану $(42,8 \%)$, удосконалення форми тіла (39\%), досягнення високого спортивного результату $(33,7 \%)$, розвиток фізичних якостей $(32,5 \%)$, покращення стану здоров'я $(28,5 \%)$, активний відпочинок, розваги $(18,2 \%)$ та спілкування з друзями $(16,9 \%)$.

Висновки. Отже, результати опитування студентів показали загалом позитивне ставлення студентів до занять з фізичного виховання у закладі вищої освіти, але юнаки бажають покращити деякі особливості проведення занять. Також виявлене бажання студентів займатися додатково у позанавчальний час. Одним із напрямків фізичної активності, що викликає інтерес у студентів, є заняття єдиноборствами, зокрема, тайським боксом. Ці дані дають підстави пропонувати студентам заняття тайським боксом в секційній формі з метою корекції фізичного стану.

\section{Література:}

1. Власов Г.В. Вивчення динаміки спортивних уподобань студентів вищих медичних навчальних закладів. Науковий вісник Донбасу. 2011. № 1. Режим доступу: http://nbuv.gov.ua/UJRN/nvd_2011_1_15.

2. Гринько В. М. Ставлення студентів до фізичного виховання $\mathrm{i}$ здорового способу життя та їх самооцінка рівня фізичної підготовленості. Слобожанський науково-спортивний вісник. 2015. № 1(45). C. 55-59.

3. Захаріна Є.А. Формування мотивації до рухової активності у процесі фізичного виховання студентів вищих навчальних закладів: автореф. дис. на здобуття наук. ступ. канд. наук 3 фіз. виховання $\mathrm{i}$ спорту: 24.00.02. Київ, 2008. 21 с.

4. Корж Н. Ефективність технології формування ціннісного ставлення студентів до фізичної культури в процесі самостійних занять. Спортивний вісник Придніпров'я. 2017. № 3. С. 59-64.

5. Півень О.П. Мотиваційно-ціннісне ставлення студентів до фізкультурно-оздоровчої діяльності. Молодий вчений. 2018. № 4.2 (56.2). С. 29-32.

6. Теорія і методика фізичного виховання: підручник для студ. вузів фіз. вихов. і спорту: в 2 т. / За ред. Т.Ю. Круцевич. Київ: Олімпійська література, 2017. 200 